\title{
Effects of copper(II) and copper oxides on THMs formation in copper pipe
}

\author{
Bo $\mathrm{Li}^{\text {a,b }}$, Jiuhui $\mathrm{Qu}^{\mathrm{a}, *}$, Huijuan Liu ${ }^{\text {a }}$, Chengzhi $\mathrm{Hu}^{\mathrm{a}}$ \\ ${ }^{a}$ State Key Laboratory of Environmental Aquatic Chemistry, Research Center for Eco-Environmental Sciences, Chinese Academy of Science, \\ 18 Shuangqing Road, Haidan District, Beijing 100085, PR China \\ ${ }^{\mathrm{b}}$ Graduate School of the Chinese Academy of Sciences, Beijing 100039, PR China
}

Received 10 November 2006; received in revised form 30 January 2007; accepted 30 January 2007

Available online 23 March 2007

\begin{abstract}
Little is known about how the growth of trihalomethanes (THMs) in drinking water is affected in copper pipe. The formation of THMs and chlorine consumption in copper pipe under stagnant flow conditions were investigated. Experiments for the same water held in glass bottles were performed for comparison. Results showed that although THMs levels firstly increased in the presence of chlorine in copper pipe, faster decay of chlorine as compared to the glass bottle affected the rate of THMs formation. The analysis of water phase was supplemented by surface analysis of corrosion scales using X-ray photoelectron spectroscopy (XPS), scanning electron microscope $(\mathrm{SEM})$ and energy dispersive spectroscopy (EDX). The results showed the scales on the pipe surface mainly consisted of $\mathrm{Cu}_{2} \mathrm{O}, \mathrm{CuO} \mathrm{and}$ $\mathrm{Cu}(\mathrm{OH})_{2}$ or $\mathrm{CuCO}_{3}$. Designed experiments confirmed that the fast depletion of chlorine in copper pipe was mainly due to effect of $\mathrm{Cu}_{2} \mathrm{O}$, $\mathrm{CuO}$ in corrosion scales on copper pipe. Although copper(II) and copper oxides showed effect on THMs formation, the rapid consumption of chlorine due to copper oxide made THM levels lower than that in glass bottles after $4 \mathrm{~h}$. The transformations of CF, DCBM and CDBM to BF were accelerated in the presence of copper(II), cupric oxide and cuprous oxide. The effect of $\mathrm{pH}$ on THMs formation was influenced by effect of $\mathrm{pH}$ on corrosion of copper pipe. When $\mathrm{pH}$ was below 7, THMs levels in copper pipe was higher as compared to glass bottle, but lower when $\mathrm{pH}$ was above 7.
\end{abstract}

(c) 2007 Elsevier Ltd. All rights reserved.

Keywords: Copper pipe; Cuprites; THMs; DBPs; Chlorination; Disinfection

\section{Introduction}

Chlorination of drinking waters containing organic carbon and bromide ion results in the formation of potentially carcinogenic disinfection byproducts (DBPs). Trihalomethanes (THMs) are the most commonly DBPs, which including chloroform $(\mathrm{CF})$, bromodichloromethane $(\mathrm{BDCM})$, dibromochloromethane (DBCM) and bromoform (BF). More attention has been paid on eliminating THMs precursors during water treatment. However, treated water will spend a considerable amount of time in distribution system before being consumed. It is important to

\footnotetext{
* Corresponding author. Tel.: +8610 62849151; fax: +86 1062923558 E-mail address: jhqu@rcees.ac.cn (J. Qu).
}

understand the possible growth of DBPs over this time. It is not unusual to see levels of these compounds at the tap that are two to three times higher than what they are leaving the treatment work (Rossman et al., 2001).

Copper is widely used for tubing and pipe in the distribution systems of drinking water throughout the world due to its excellent corrosion resistance and its killing effect on certain bacterial specie (Feng et al., 1996). Although copper is a relatively noble metal, it reacts easily in ordinary oxygen-containing electrolyte (Hukovic et al., 2000). In the past several decades, intensive studies focused on the corrosion of copper pipe in water. Copper ion was released and copper oxides were formed on the pipe wall during copper corrosion (Merkel et al., 2002). Excess amount of copper released from copper pipes results in the green-blue 
colored water and is a threat to human health. However, little is known about how the growth of trihalomethanes (THMs) in drinking water is affected by copper pipe in the distribution system.

A limited number of studies have reported a catalysis effect of copper in THMs formation. Barnes et al. (1979) conducted experiments testing the influence of copper on reactions of humic substances with chlorine. Blatchley et al. (2003) investigated the catalysis effect of copper on a number of known THMs precursors. Copper and copper oxides have been reported to be effective as catalysis species in many reactions. In the case of inorganic decomposition, copper-based catalysts are used in many chemical processes, including decomposition of nitrous oxide (Luys et al., 1989) and hydrogen peroxide (Onuchukwu, 1994). In the case of organic oxidation, copper and copper oxides also participate as catalyst in many reactions including: oxidation of propene (Amariglio et al., 1989) and aqueous phenol solutions (Pintar et al., 1997).

Based on the findings of the studies described above, it is hypothesized that copper and copper oxides could play an important role in the THMs formation and the chlorine consumption in copper pipe upon chlorination of water supplies. The objective of the work described here was to investigate the formation of THMs in copper pipe in stagnation experiments during the chlorination of drinking water containing humic acid (HA) and bromide ion. The difference of THMs formation and the chlorine consumption in copper pipe and in glass bottle may be due to the effects of copper released and the copper oxides formed on the pipe wall. To test the hypothesis, the surface character of copper pipe was determined by XPS, SEM and EDX and the copper released was measured during the stagnation experiments. To further explain the THMs formation in copper pipe, designed experiments were conducted with copper(II), cupric oxide and cuprous oxides. Their influences on the consumption of chlorine and the formation of THMs were performed in glass bottles.

\section{Materials and methods}

\subsection{Chemicals}

All chemical solutions were prepared from reagent grade chemicals or stock solutions. Sodium hypochlorite $(\mathrm{NaOCl}>10 \%$ available chlorine) was used as the source of chlorine and periodically standardized by DPD methods. A humic acid stock solution was prepared by dissolving humic acid crystals into deionized water and filtering the solution through a $0.45 \mu \mathrm{m}$ filter paper.

Standard solutions of copper(II) and four trihalomethanes (CF, BDCM, DBCM and BF) were purchased from Chinese National Research Centre for Certified Reference Materials and prepared in deionized water.

Copper(II) used in these experiments was added to the test water in the form of copper sulfate $\left(\mathrm{CuSO}_{4} \cdot 5 \mathrm{H}_{2} \mathrm{O}\right.$, reagent grade). Cupric oxide and cuprous oxide were pur- chased from Bei Hua Fine Chemicals Limited Company (Beijing, China) and Tianjin FuChen Chemical Reagent Factory (China).

\subsection{Analysis methods}

Standards and samples for THM analysis were extracted using hexane (HPLC grade). A gas chromatograph (Agilent $6890 \mathrm{~N}$ Series, Japan) with an electron capture detector was used for determining THMs by using an USEPA method 552.1. Separation of species was achieved with a HP-5 fused silica capillary column $(30 \mathrm{~m} \times 0.32 \mathrm{~mm} \times$ $0.25 \mu \mathrm{m}$ ) under the temperature program: $35^{\circ} \mathrm{C}$ for $4 \mathrm{~min}$, ramp to $100{ }^{\circ} \mathrm{C}$ at $10^{\circ} \mathrm{C} / \mathrm{min}$ and hold $3 \mathrm{~min}$. Nitrogen gas of extra purity ( $>99.999 \%)$ was used as a carrier gas.

The concentration of total organic carbon was analyzed using a Multi N/C 3000 TOC analyzer (AnalytikjenaAG, Germany).

Chlorine was measured using the $N, N$-diethyl-p-phenylenediamine (DPD) by UV-spectrophotometer at $510 \mathrm{~nm}$.

Copper(II) was determined by Atomic Absorption Spectrophotometer 3100 (AAS, USA, PekinElmer, Co.).

Specific surface area was obtained by an ASAP 2000 surface analyzer (Micromeritics Co. USA) and using $\mathrm{N}_{2}$ adsorption.

X-ray photoelectron spectroscopy (XPS) surface analysis was performed by Thermo VG scientific (UK) with AlKa radiation.

A conformation of the identity and elemental composition of the oxide film was obtained by conducting an SEM analysis using Field Emission Scanning Electron Microscope Instrument XL-30 (USA) with EDX capability.

\subsection{Pipe rig tests}

Pipe rig tests were used to illustrate the changes of THMs formation in response to water quality changes and aging in copper pipe. The rigs were $20 \mathrm{in}$. long, $1 / 2 \mathrm{in}$. diameter tubes with a volume of approximately $80 \mathrm{ml}$. Many rubber stoppers wrapped with Teflon tape were used to plug the ends of each tube.

The test water derived from Beijing tap water was treated with a GAC canister to remove residual chlorine, THMs and possible THMs precursors. The pipes were filled with test water after being carefully rinsed three times with deionized water. The reactants were added to the test water in the following order: humic acid, $\mathrm{KBr}$, chlorine in the form of $\mathrm{NaOCl}$ and then $\mathrm{pH}$ was adjusted with $\mathrm{HCl}$ and $\mathrm{NaOH}$. After reactants introduction, the pipes were sealed and lay horizontally at $20^{\circ} \mathrm{C}$ in the dark.

To avoid the error resulting from the volatilization of THMs, the copper pipes were headspace free. Water samples were taken from different pipes after $1,2,4,8,12$, $24 \mathrm{~h}$ and measured residual chlorine, copper concentration and THMs. In the case of determining the effect of $\mathrm{pH}(5$, $6,7,8$ and 9), the water samples were withdrawn from different pipes with different $\mathrm{pH}$ after $15 \mathrm{~h}$ immersion and 
measured residual chlorine, copper concentration and THMs. A parallel experiment was run in glass bottles for a comparison. Experiments were repeated three times (each) in copper pipes and in glass bottles.

\subsection{Designed experiments}

In order to determine the dosage of copper and copper oxides, preliminary chlorination experiments with varying concentration of copper and copper oxides were performed. Results showed that it had little effect on the chlorine consumption when the dosages of copper oxides were below $100 \mathrm{mg}^{-1}$. In order to demonstrate the effect of copper oxides more clearly, their dosages were chosen to higher levels.

In the case of testing effect on chlorine consumption, 1 and $5 \mathrm{mg}^{-1}$ of copper(II); 332 and $3320 \mathrm{mg} \mathrm{l}^{-1}$ of cuprous oxide; 332 and $3320 \mathrm{mg}^{-1}$ of cupric oxide were added to $250 \mathrm{ml}$ aqueous solution containing $17.5 \mathrm{mg}^{-1}$ of chlorine respectively in sealed $250 \mathrm{ml}$ glass bottles. In the case of testing effect on THMs formation, $2.5 \mathrm{mg}^{-1}$ of copper(II); $3320 \mathrm{mg}^{-1}$ of cuprous oxide and cupric oxide respectively were added to $1000 \mathrm{ml}$ aqueous solution containing $4.8 \mathrm{mg} \mathrm{l}^{-1}$ of humic acid, $19.6 \mathrm{mg} \mathrm{l}^{-1}$ of chlorine and $3 \mathrm{mg}^{-1}$ of bromine in sealed $1000 \mathrm{ml}$ glass bottles.

The containers were placed into an automated shaker and shaken at $130 \mathrm{rpm}$ in the dark at $20^{\circ} \mathrm{C}$. Samples were periodically withdrawn from the glass bottles to detect THMs and residual chlorine.

\section{Results and discussion}

\subsection{Effect of exposure time}

Fig. 1a presents the THMs formation in copper pipes and in glass bottles as a function of time. An initial free chlorine dose of $11.5 \mathrm{mg}^{-1}$ was used to achieve a concentration of $7.5 \mathrm{mg}^{-1}$ entering the pipes. These data illustrate a pattern of more increased THMs formation rate in copper pipes than in glass bottles during the first $4 \mathrm{~h}$, however, less THMs formation after $4 \mathrm{~h}$.

It can be explained by the difference of depletion of chlorine in copper pipe and in glass bottle (Fig. 1b). The chlorine residual were consistently and continuously consumed with time in both pipe materials. Clearly, the residual concentration in copper pipes was substantially lower than those in glass bottles. It depleted almost completely in copper pipes, but remained $53.6 \%$ in glass bottles after $4 \mathrm{~h}$. It is widely accepted that chlorine in distribution systems will decay, either due to reactions with compounds contained within the bulk water (bulk decay), which can be reflected by the consumption of chlorine in glass bottles, or due to reactions at the pipe wall (wall decay). Chlorine decay in copper pipe was the integration above. The rapid consumption of chlorine in copper pipe should due to the wall decay. Rossman et al. (2001) also find the same phenomena in unlined ductile iron pipe at similar $\mathrm{pH}$ range, that is, the
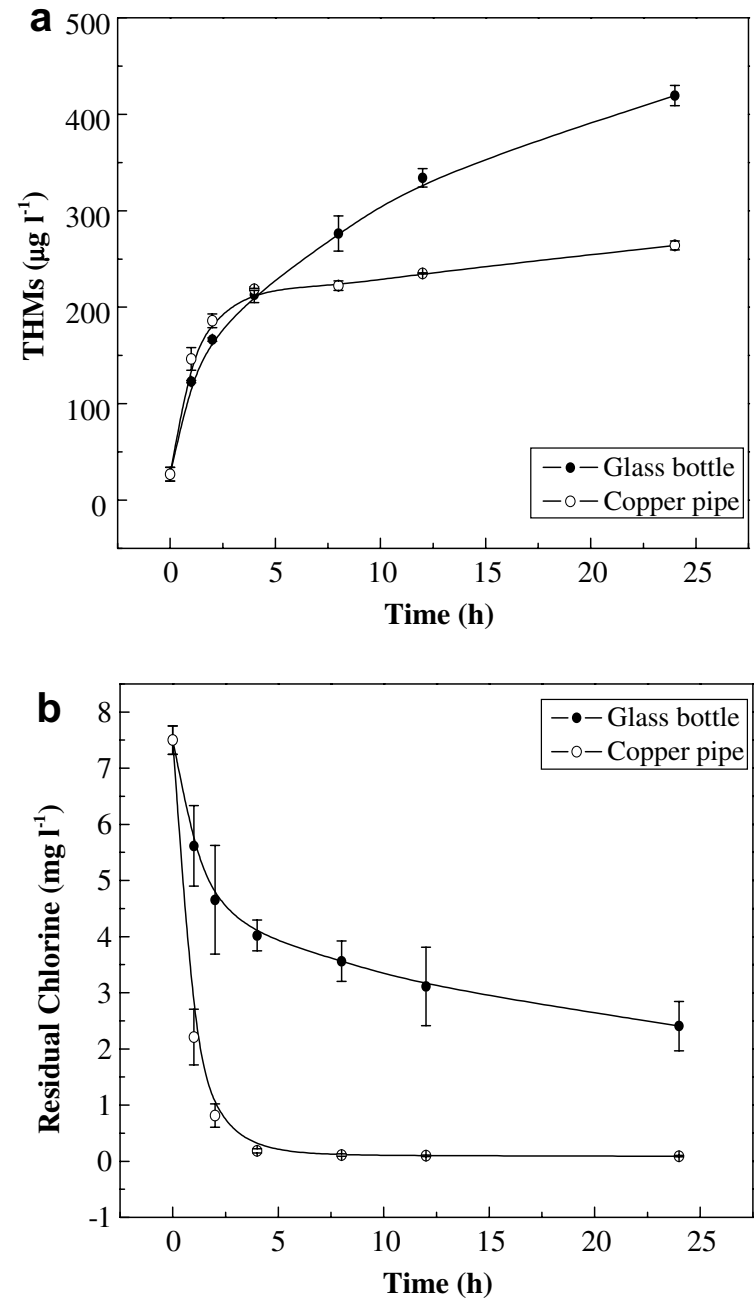

Fig. 1. THMs formation (a) and chlorine decay (b) as a function of time. Experimental conditions were $\mathrm{pH}=7.7$; humic acid concentration $=5.7 \mathrm{mg} \mathrm{l}^{-1}$; initial chlorine concentration $=7.5 \mathrm{mg}^{-1}$; initial bromine concentration $=3 \mathrm{mg} \mathrm{l}^{-1}$, temperature $=20^{\circ} \mathrm{C}$. Experiments were repeated three times (each) in copper pipes and in glass bottles. Data points correspond to the mean of THMs or chlorine measurements for each sampling time, with the error bars corresponding to the standard deviation.

rate of chlorine decay in the pipe due primarily to nonDBP reactions was an order of magnitude higher than in the glass bottle. However, there was no reduction of the rate at which THMs was produced in their studies. This could be due to that the chlorine consumption in unlined ductile iron pipe was slower than in copper pipe, still $25 \%$ of residual chlorine in unlined ductile iron pipe at $10 \mathrm{~h}$, but depletion of chlorine was completed in copper pipe at $4 \mathrm{~h}$.

It should be noticed that the rate of THMs formation in copper pipes was faster at the first $4 \mathrm{~h}$ when the chlorine rapidly depleted. After $4 \mathrm{~h}$, chlorine in copper pipes depleted entirely to eliminate one of the reactants of THMs formation. By comparison, the formation of THMs in glass bottles was slower at first $4 \mathrm{~h}$ than that in copper pipes, but increased continuously during the $24 \mathrm{~h}$ exposure because of the slower depletion of chlorine. Owing to the above 
reactions, THMs levels in copper pipe were always lower than that in glass bottles in stagnant experiments above $4 \mathrm{~h}$ reaction time.

\subsection{Surface characters of copper pipe}

As mentioned above, chlorine depletion was fast and a consistently higher level of THMs was produced in copper pipes at first $4 \mathrm{~h}$ as compared to the bottles. It could be due to the strong oxidizing capability of chlorine resulting copper(II) released from the wall of copper pipe to water and formation of scales attached to the pipe wall. In fact, this process has two effects: (i) It consumed the chlorine. (ii) The copper(II) produced in the process and the formed scales have effects on the chlorine consumption and THMs formation. Hence the concentration of copper(II) during the exposure time and the scales characters of copper pipe were determined. It was found that the concentration of copper(II) in copper pipes increased to $3.1 \mathrm{mg} \mathrm{l}^{-1}$ after $4 \mathrm{~h}$ and decreased to $2.5 \mathrm{mg}^{-1}$ at $24 \mathrm{~h}$.

In drinking water possible oxidants for dissolution (or oxidation) of copper are residual chlorine and dissolved oxygen. Reaction of copper metal with chlorine in water can be the following reaction (Hong and Macauley, 1998):

$$
\begin{aligned}
& \mathrm{HClO}+\mathrm{Cu}(\mathrm{s}) \Longleftrightarrow \mathrm{CuO}(\mathrm{s})+\mathrm{H}^{+}+\mathrm{Cl}^{-} \log K=31.8 \mathrm{M} \\
& \mathrm{HClO}+\mathrm{Cu}(\mathrm{s})+\mathrm{H}_{2} \mathrm{O} \Longleftrightarrow \mathrm{Cu}(\mathrm{OH})_{2}(\mathrm{~s})+\mathrm{H}^{+}+\mathrm{Cl}^{-} \log K=30.5 \mathrm{M}
\end{aligned}
$$

$\mathrm{HClO}+\mathrm{Cu}(\mathrm{s})+\mathrm{HCO}_{3}^{-} \Longleftrightarrow \mathrm{CuCO}_{3}(\mathrm{~s})+\mathrm{H}_{2} \mathrm{O}+\mathrm{Cl}^{-} \log K=38.4 \mathrm{M}^{-1}$

The large equilibrium constants of the above reactions show the strong oxidizing capability of chlorine toward elemental copper. In addition, other reactions may occur in copper pipe:

$$
\begin{aligned}
& \mathrm{Cu} \rightarrow \mathrm{Cu}^{+}+\mathrm{e}^{-} \\
& \mathrm{Cu}^{+}+\frac{1}{2} \mathrm{H}_{2} \mathrm{O} \Longleftrightarrow \frac{1}{2} \mathrm{Cu}_{2} \mathrm{O}+\mathrm{H}^{+} \\
& \frac{1}{2} \mathrm{Cu}_{2} \mathrm{O}+\mathrm{H}^{+} \Longleftrightarrow \mathrm{Cu}^{2+}+\frac{1}{2} \mathrm{H}_{2} \mathrm{O}+\mathrm{e}^{-}
\end{aligned}
$$

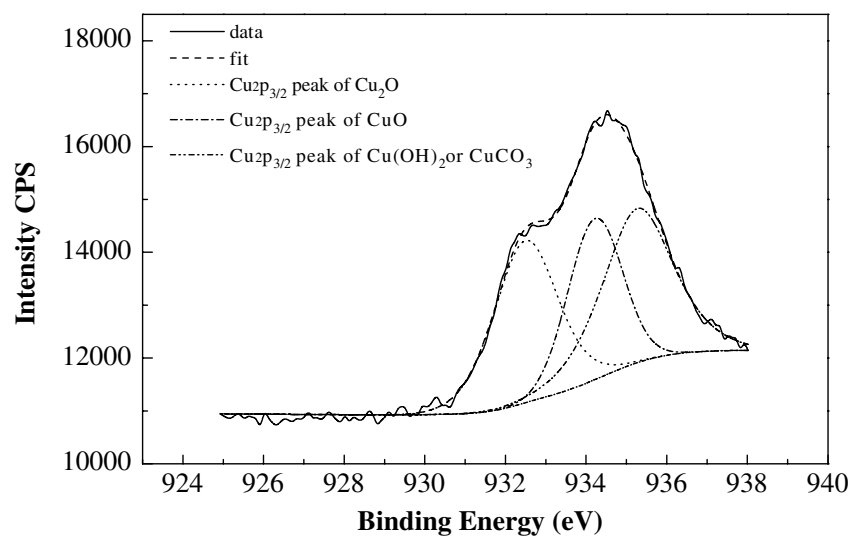

Fig. 2. Cu2p XPS spectra of the oxide film formed after six days immersion (initial chlorine concentration $=11.5 \mathrm{mg}^{-1}, \mathrm{pH}=7.7$, temperature $=20^{\circ} \mathrm{C}$ ).
According to Eqs. (1)-(3) and (5), it can deduce that cupric oxide, cuprous oxide and cupric hydroxide or cupric carbonate were all incorporated into the corrosion scale.

Fig. 2 shows the results of $\mathrm{Cu} 2 \mathrm{p}_{3 / 2}$ XPS spectra of the formed oxides film of copper pipe after six days immersion
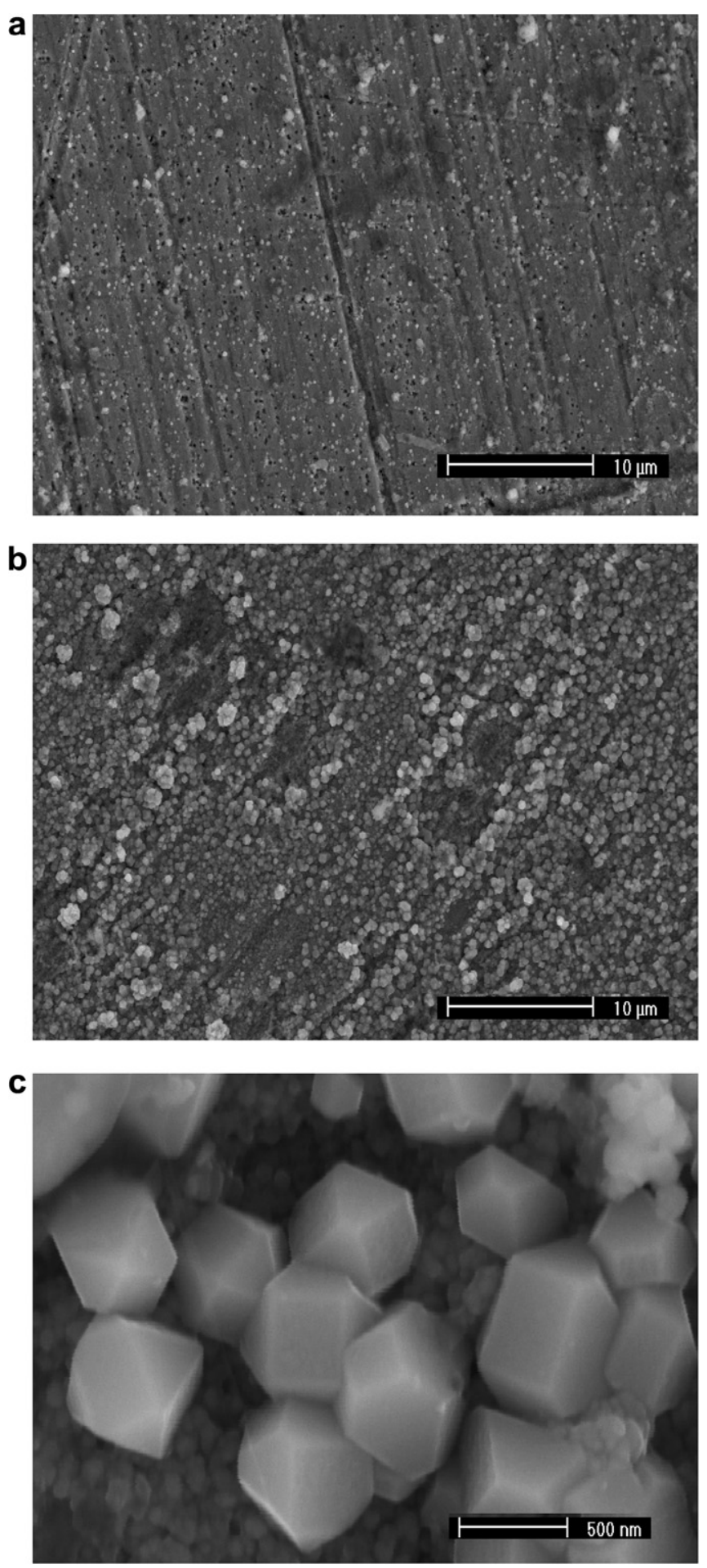

Fig. 3. An SEM photograph of copper surfaces (a) before immersion; (b) after six days immersion $(2000 \times$ magnification) and (c) after 6 days immersion $(30000 \times$ magnification $)$. Experimental conditions were $\mathrm{pH}=$ 7.7; initial chlorine concentration $=11.5 \mathrm{mg}^{-1}$; temperature $=20^{\circ} \mathrm{C}$. 
in chlorinated water. The three peaks at binding energies of 932.5, 934, and $935 \mathrm{eV}$ represent $\mathrm{Cu}_{2} \mathrm{O}, \mathrm{CuO}$ and $\mathrm{Cu}(\mathrm{OH})_{2}$ or $\mathrm{CuCO}_{3}$, respectively. The inner wall of copper pipe after six days immersion had two colors, one was brown and another was green and black. We analyzed the two parts of the pipe which represent the upper and lower respectively. It can be concluded that the scale on the pipe surface mainly consist of $\mathrm{Cu}_{2} \mathrm{O}, \mathrm{CuO}$ and $\mathrm{Cu}(\mathrm{OH})_{2}$ or $\mathrm{CuCO}_{3}$ (22.2-34.3\%, 28.3-57.1\%, 20.7-37.5\%, respectively).

To confirm the XPS findings, SEM and EDAX analyses were conducted on the scales surface. Fig. 3 shows SEM photomicrography of the inner face of the corrosion products formed (a) before and (b) after immersion in chlorination water. The oxide film before immersion was slicker with cavity. By comparison, crystal growth was found on the surface of the scales after six days immersion. According to the EDAX spectra the observed octahedral crystals correspond to cuprites. The copper to oxygen ratios for the samples (atomic percentages) were in the vicinity of 10:1 for the oxide film before immersion and about 2:1, 1:1 for black part and green part of the scales after six days immersion respectively. The low ratio of cupric species to oxygen means the copper pipe surfaces were well protected by the cupric and cuprous oxides.

\subsection{Designed experiments}

\subsubsection{Effect on chlorine depletion}

Experiments were run with deionized water chlorinated to the same levels, in the presence of copper(II), cuprous oxide and cupric oxide respectively.

The results are displayed in Fig. 4. For the lower dosages (1, 332 and $332 \mathrm{mg}^{-1}$ for copper(II), cupric oxide and cuprous oxide, respectively), the addition of the copper(II) and cupric oxide to the system yielded a little decrease in chlorine consumption, obvious decrease in the

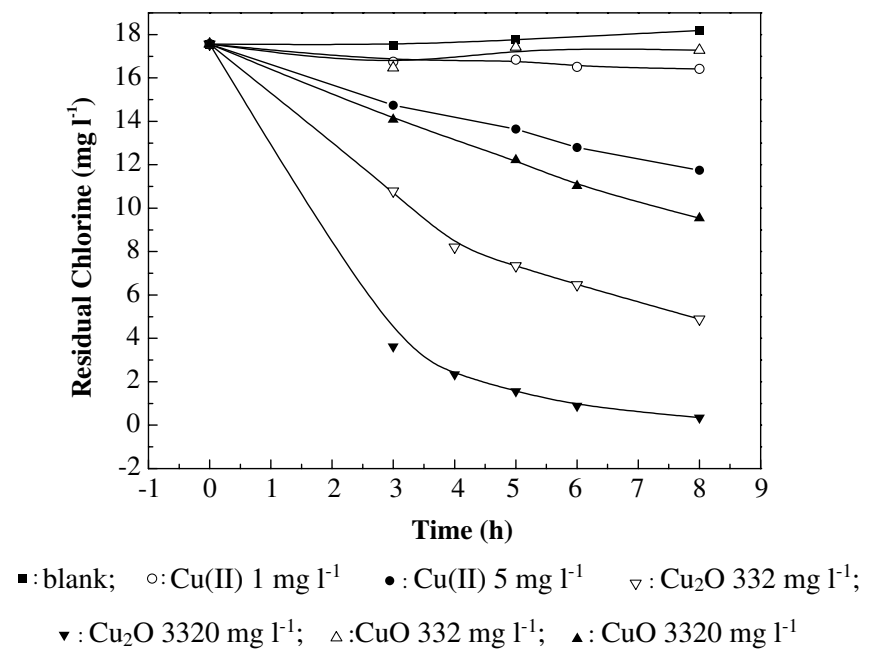

Fig. 4. Chlorine consumption as a function of time. Experimental conditions were $\mathrm{pH}=7.7$; initial chlorine concentration $=17.5 \mathrm{mg} \mathrm{l}^{-1}$; temperature $=20^{\circ} \mathrm{C}$. case of cuprous oxide. For the higher dosages $(5,3320$ and $3320 \mathrm{mg}^{-1}$ for copper(II), cupric oxide and cuprous oxide, respectively), remarkable decrease was observed in the case of three materials, after $8 \mathrm{~h}$ of exposure time the residual chlorine was $66.8 \%, 54.3 \%, 2 \%$ for copper(II), cupric oxide and cuprous oxide respectively. Under experiment condition, the maximal copper released in copper pipe was below $5 \mathrm{mg}^{-1}$. As mentioned above, for initial copper(II) concentrations of $5 \mathrm{mg}^{-1}$, its effect on chlorine consumption was limited. Hence the presence of copper(II) was not the main reason of the fast depletion of chlorine in copper pipe. It could be concluded that the reaction of chlorine with copper oxides was the main aspects. For the same dose, the cuprous oxide shows more effect on chlorine depletion as compared to cupric oxide. The surface area measured via BET was 4.229 and $9.4784 \mathrm{~m}^{2} \mathrm{~g}^{-1}$ for cupric oxide and cuprous oxide, respectively. Bigger special surface area of cuprous oxide provided more contact sites to water than that of cupric oxide on the same dose of weight, which was a reason of more obvious effect of cuprous oxide on chlorine depletion than cupric oxide.

\subsubsection{Effect on THMs formation}

The effects of copper and copper oxides on THMs formation are illustrated in Fig. 5a. Clearly, the presence of copper(II) and cupric oxide had a more profound effect on THMs formation. The formation of THMs after $24 \mathrm{~h}$ were 507.6, 756.7, 561 and $323.9 \mu \mathrm{g} 1^{-1}$ for glass bottle, copper(II), cupric oxide and cuprous oxide, respectively.

After $4 \mathrm{~h}$, THMs formation in the presence of cuprous oxide was lower than that in the absence of copper, which showed a similar tendency in copper pipe. The catalysis action of copper(II) and cupric oxide increased with increasing time. From $1 \mathrm{~h}$ to $12 \mathrm{~h}$ the THMs level increased from $118 \%$ to $135 \%$, and from $119 \%$ to $125 \%$ in the presence of copper(II) and cupric oxide, respectively.

It could be concluded that due to the effect of copper oxides on chlorine consumption, the chlorine in copper pipe depleted completed at $4 \mathrm{~h}$. The rate of consumption of chlorine in copper pipe was 6.4 times faster than that in glass bottle at $4 \mathrm{~h}$. The THMs formation in copper pipe increased $116 \%$ than that in glass bottle at $4 \mathrm{~h}$. It is well known that more the chlorine dosage more will be the formation of THMs. At first $4 \mathrm{~h}$, the rapid consumption of chlorine influenced the formation of THMs. Although the effect of copper(II) and cupric oxide on THMs formation, only a limited increased was observed during the $4 \mathrm{~h}$ in copper pipe, then due to the reactant, chlorine, was absent, the THMs formation almost stopped. By comparison, the formation of THMs in glass bottles increased continuously during the $24 \mathrm{~h}$ exposure because of the slower depletion of chlorine, which resulted in the lower THMs level in copper pipe than in glass bottle above $4 \mathrm{~h}$ immersion time.

3.3.2.1. THM speciation. Comparisons of THMs speciation in the absence of copper and in the presence of copper(II), 

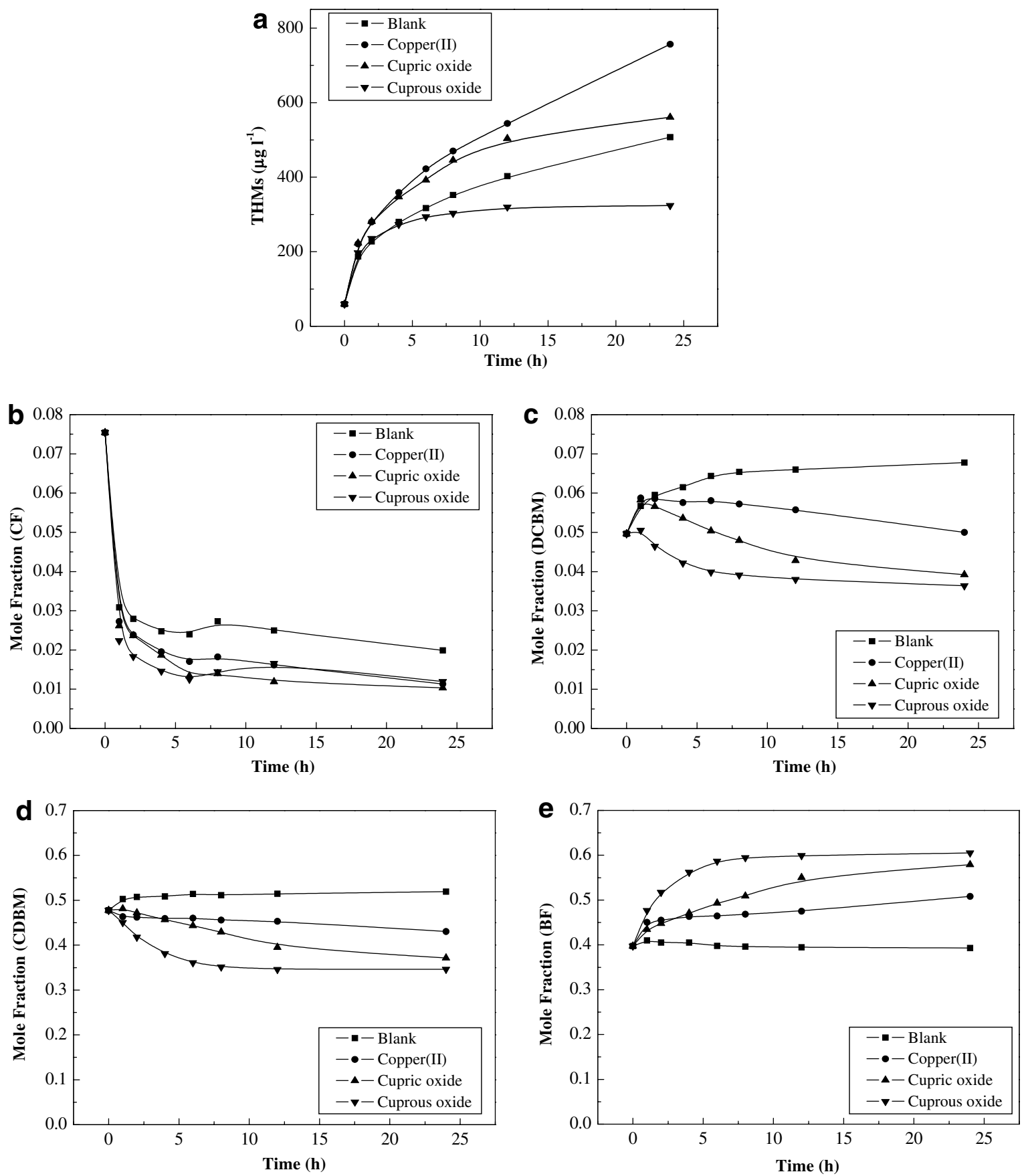

Fig. 5. THMs formation (a) and THMs speciation in the absent of copper compared to in the present of copper(II), cupric oxide and cuprous oxide (b) CF (c) $\operatorname{DCBM}$ (d) $\operatorname{CDBM}$ (e) BF. Experimental conditions were $\mathrm{pH}=7.7$; humic acid concentration $=4.8 \mathrm{mg}^{-1}$; initial chlorine concentration $=$ $19.6 \mathrm{mg} \mathrm{l}^{-1}$; initial bromine concentration $=3 \mathrm{mg} \mathrm{l}^{-1}$; temperature $=20^{\circ} \mathrm{C}$.

cupric oxide and cuprous oxide are shown in Fig. 5b-e. Mole fractions for four measured THMs species are compared: CF, DCBM, CDBM and BF. Fig. 5 shows the changes of THMs species as a function of time in the absence of copper: (i) the mole fraction of CF decreased; (ii) the mole fraction of DCBM increased; (iii) the mole fraction of CDBM increased slightly; (iv) the mole fraction of BF maintained at $40 \%$. Obvious difference was observed in the presence of copper(II), cupric oxide and cuprous oxide: (i) the mole fraction of $\mathrm{CF}$ decreased which was similar with that in the absence of copper; (ii) the mole fraction of DCBM increased at first $1 \mathrm{~h}$ and then decreased; (iii) the mole fraction of CDBM decreased; (iv) the mole fraction of $\mathrm{BF}$ increased. It should be noted that the mole fractions for four THMs species in copper pipe have the similar tendency with that in the presence of copper (the results were not reported). It could be concluded that the transformations of CF, DCBM 
and $\mathrm{CDBM}$ to $\mathrm{BF}$ were accelerated in the presence of copper.

\subsection{Effects of $p H$}

Fig. 6 demonstrates the effect of $\mathrm{pH}$ on the formation of THMs. As shown in Fig. 6, the formation of THMs in copper pipe was similar in glass bottle which increased with increasing $\mathrm{pH}$. However, there are more THMs formation in copper pipe at $\mathrm{pH}$ below 7 and less when $\mathrm{pH}$ above 7 .

The THMs level in glass bottle increased from 79 to $267.9 \mu \mathrm{g}^{-1}$ with the increasing of $\mathrm{pH}$ from 5 to 9 . The effect of $\mathrm{pH}$ on the formation of THMs in glass bottle has been observed by others (Reckhow et al., 1990; Liang and Singer, 2003). In acid solution, the majority of free chlorine will be $\mathrm{HOCl}$ which extensive participates in electrophilic addition and substitution reactions. With increasing of $\mathrm{pH}$, base-catalyzed hydrolysis would prevail, thus giving more chloroform. It was found that the corrosion rate of copper is influenced by the $\mathrm{pH}$. There was nearly $50 \mathrm{mg}^{-1}$ copper(II) released from copper pipe at $\mathrm{pH} 5$ and $0.65 \mathrm{mg} \mathrm{l}^{-1}$ at $\mathrm{pH} 10$. Brusic et al. (1991) found that the stable oxides of copper can be formed reversibly in the $\mathrm{pH}$ range $8-12$. It could be concluded that the catalysis of copper oxide played a major effect on faster chlorination depletion in based solution, made the THMs formation in copper pipe less than in glass bottles. At $\mathrm{pH}$ value below 7 , the dissolution of copper becomes significant, especially below $\mathrm{pH} 5$, where the formation of stable surface oxides is not possible. Copper(II) had a less effect on chlorination consumption, which meant chlorine exist in system for a more time and due to the obvious catalyst effect of copper(II) on THMS formation, more THMs formed in copper pipe than in glass bottle. It could be concluded that $\mathrm{pH}$ has influences on copper(II) released and the composition of scales on the copper pipes which effected the THMs formation in the copper pipe further.

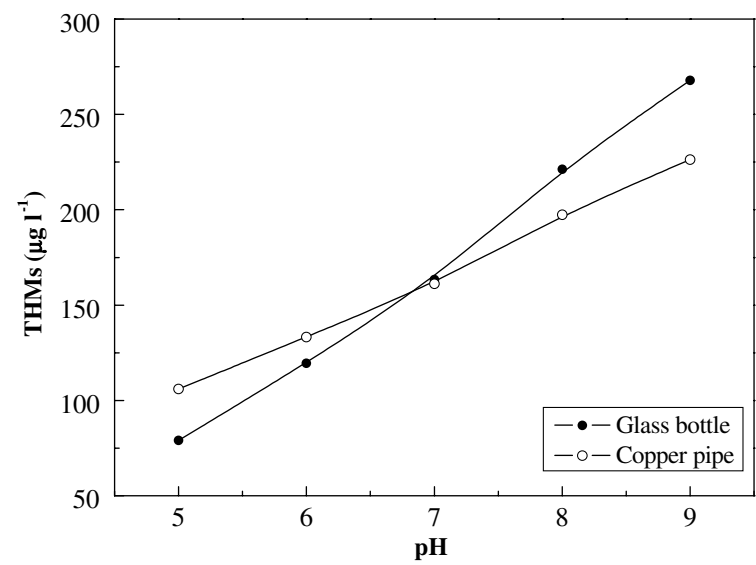

Fig. 6. THMs formation as a function of $\mathrm{pH}$. Experimental conditions were humic acid concentration $=5.7 \mathrm{mgl}^{-1}$; initial chlorine concentration $=16.1 \mathrm{mg} \mathrm{l}^{-1}$; initial bromine concentration $=0.5 \mathrm{mg}^{-1}$.

\section{Conclusion}

The combination of pipe rig tests, surface character analysis of copper pipe and designed experiments in this study lead to the following conclusions:

1. In combination with XPS, SEM and EDAX analysis, it could be concluded that the corrosion scale on the copper pipe surface in chlorinated water mainly consisted of $\mathrm{Cu}_{2} \mathrm{O}, \mathrm{CuO}$ and $\mathrm{Cu}(\mathrm{OH})_{2}$ or $\mathrm{CuCO}_{3}$.

2. Copper(II), cupric oxide and cuprous oxide all have effects on chlorine depletion. Copper oxides played a major effect on rapid consumption of chlorine than copper(II) in copper pipe.

3. Copper(II) and cupric oxide have significant effect on THMs formation. A little higher THMs level was found in the presence of cuprous oxide in the first $2 \mathrm{~h}$ due to the rapid consumption of chlorine (only $0.06 \%$ of residual chlorine remained at $4 \mathrm{~h}$ ).

4. The transformations of CF, DCBM and CDBM to BF were accelerated in the presence of copper, which result in obvious difference of THMs species in the presence and absence of copper.

5. $\mathrm{pH}$ value has a significant effect on THMs formation in copper pipe. It could be concluded that $\mathrm{pH}$ has influences on copper(II) released and the composition of scales on the copper pipes which effected the THMs formation in the copper pipe further.

\section{Acknowledgements}

The authors appreciate the generous financial support of this work by the Funds for Creative Research Groups of China (Grant No. 50621804) and by International Copper Association Ltd (H-AS-04-03).

\section{References}

Amariglio, A., Benali, O., Amariglio, H., 1989. Oscillating oxidation of propene on copper oxides. J. Catal. 118 (1), 164-174.

Barnes, D., Fitzgerald, P.A., Swan, H.B., 1979. Catalyzed formation of chlorinated organic materials in water. Water Sci. Technol. 21 (2), 59 63.

Blatchley, E.R., Margetas, D., Duggirala, R., 2003. Copper catalysis in chloroform formation during water chlorination. Water Res. 37, 43854394.

Brusic, V., Frisch, M.A., Eldridge, B.N., Novak, F.P., Kaufman, F.B., Rush, B.M., Frankel, G.S., 1991. Copper corrosion with and without inhibitors. J. Electrochem. Soc. 138 (8), 2253-2258.

Feng, Y., Teo, W.K., Siow, K.S., Tan, K.L., Hsieh, A.K., 1996. The corrosion behaviour of copper in neutral tap water Part I: Corrosion mechanisms. Corrosion Sci. 38 (3), 369-385.

Hong, P.K.A., Macauley, Y., 1998. Corrosion and leaching of copper tubing exposed to chlorinated drinking water. Water Air Soil Poll. 108, 457-471.

Hukovic, M.M., Babic, R., Paic, I., 2000. Copper corrosion at various $\mathrm{pH}$ values with and without the inhibitor. J. Appl. Electrochem. 30, 617-624.

Liang, L., Singer, P.C., 2003. Factors influencing the formation and relative distribution of haloacetic acids and trihalomethanes in drinking water. Environ. Sci. Technol. 37, 2920-2928. 
Luys, M.J., van Oeffelt, P.H., Brouwer, W.G.J., Pijpers, A.P., Scholten, J.J.F., 1989. Surface and sub-surface oxidation of copper and supported copper catalysts by nitrous oxide. Appl. Catal. 46 (1), 161-173.

Merkel, T.H., Groß, H.J., Werner, W., Dahlke, T., Reicherter, S., Beuchle, G., Eberle, S.H., 2002. Copper corrosion by-product release in long-term stagnation experiments. Water Res. 36, 1547-1555.

Onuchukwu, A.I., 1994. The effect of metal-doped copper ferrite activity on the catalytic decomposition of hydrogen peroxide. Mater. Chem. Phys. 37 (2), 129-131.
Pintar, A., Berčič, G., Levec, J., 1997. Catalytic liquid-phase oxidation of aqueous phenol solutions in a trickle-bed reactor. Chem. Eng. Sci. 52 (21/22), 4143-4153.

Reckhow, D.A., Singer, P.C., Malcolm, R.L., 1990. Chlorination of humic materials: byproduct formation and chemical interpretations. Environ. Sci. Technol. 24 (11), 1655-1664.

Rossman, L.A., Brown, R.A., Singer, P.C., Nuckols, J.R., 2001. DBP formation kinetics in a simulated distribution system. Water Res. 35 (14), 3483-3489. 